\title{
ACIMA DA CIDADE
}

Cecília Borges nasceu em Uberlândia (MG) em 1983. Reside no Rio de Janeiro. É autora de Resposta (Uberlândia: Nacional, 2001) e Dente de Leão (Porto Alegre, Editora Éblic, 2009). Atualmente é aluna de pós graduação de Letras na PUC.

E-mail: borges.cecilia@gmail.com

O grande amor não acontece para a maioria. Muitos encontros podem seguir a vida inteira por acordos e afinidades. O que não é de todo ruim, evita-se fadiga e o exercício de tolerância. A coragem é poupada também, como quando optamos por não saltar de asa delta. Outros sentimentos podem se maquiar de grande amor, surgirem sem pontadas no peito, todos inteiramente serenos, dando a impressão de completude: a tampa da panela, a metade da laranja, o sapato velho para o pé cansado. Não viver um grande amor é uma opção, inclusive aceitável. Afinal, a gente também pode ter um emprego meia boca pra pagar o aluguel e adiar solenemente a viagem aos vulcões adormecidos de Lanzarote. Sem ter vivido um grande amor ainda podemos dividir uma casa com alguém e ter filhos. O outro será admirado, respeitado e terá direito a afagos e atenção. A tranquilidade é a constante que não existe em um grande amor. E todos nós sabemos quando não estamos vivendo um pela quietação do organismo: tudo está funcionando muito bem, obrigada. $\mathrm{O}$ grande amor é um filho da puta, seu sapato não tem a numeração que a gente precisa. Provavelmente o grande amor só fará as mais doces promessas quando bêbado, o saldo dele no banco é negativo e ele tem uma maniazinha horrenda. O grande amor, depois da primeira revista, parece somente dar prejuízo e durante noites e noites e noites nos perguntamos se é este um grande amor de fábrica. Original, como o pecado, o surgimento das imperfeições humanas. Mas descobrimos rápido. E a partir daí basta preencher uma fichinha e doar cinco litros de sangue por dia. Por sorte, não teremos que subtrair o que antes eram dois dentro da gente. Vinícius escreveu que para viver um desses é preciso peito de remador. Adélia Prado diz que ele é feinho, pois é, acho que às vezes o grande amor usa a mesma camiseta durante três dias, deixa a cera de depilação na pia ou nem corta os pêlos do nariz. Mas ela também diz que uma vez encontrado, é igual fé, não teologa mais. O grande amor, quando velho, se veste de intimidade mas ainda dá disparos de grande amor. Ele é incansável, não tenta $70 \times 7$ como a conta que disseram existir pro perdão, ele insiste em dízimas periódicas. $\mathrm{E}$ o grande amor não faz o que fala, mas faz muito bem o que ficou no silêncio. Porém sempre existirá um momento crucial. Porque além de encontrar um grande amor, é preciso decidir se ele subirá até o andar da sua casa. Se os sapatos ficarão de fora para que ele entre na sua mala, divida a mesa com seus amigos declarando-os chatos no pé do seu ouvido, se o grande amor poderá entoar seus sambas enquanto você assovia Cole Porter, se ele poderá reclamar do seu cigarro, cobrar sua presença. Porque o grande amor precisa viver junto e este bilhete premiado vem com cláusulas difícies e preciosas, porque o grande amor não acontece pra maioria. 
Aconteceu com você. Então é necessário decidir se poderá mudar isso e aquilo pra viver um grande amor... poxa, nem tudo na vida teve $90 \%$ de aprovação. E se decidir vivê-lo: coisas prateadas espocam, seu olho vê dentro de diamantes, o mar cabe na cama, acorda-se porquinho da índia, nega-se leis da gravidade facilmente (Chagall sabia disso), surgem comparações dementes do grande amor com summer nights in Spain, Garbo's salary e docinho de coco, além da criação natural e imediata de um dialeto nunca visto pela humanidade e nem por você antes de deixar o grande amor subir até o seu andar. E as rosas falam sim. 